\title{
To'-oto'- The Local Wisdom of Madurese Ethnic Families and Perceptions
}

\author{
Ferdiya Devika ${ }^{*}$ Maretha Ika Prajawati ${ }^{2}$ Basir.S $^{3}$ \\ 1.2 Faculty of Economics, Maulana Malik Ibrahim Islamic State University of Malang \\ 3 School of Strategic \& Global Studies, University of Indonesia \\ Corresponding Author: ferdiyadevika26@gmail.com
}

\begin{tabular}{|c|c|}
\hline & Abstract \\
\hline $\begin{array}{l}\text { Keywords: } \\
\text { To'-oto', Madurese } \\
\text { Ethnicity, Perception. }\end{array}$ & $\begin{array}{l}\text { The to'-oto' a tradition is an event held by the community to return } \\
\text { bhubuwan's money (money given at weddings). Each implemented } \\
\text { certainly has different perceptions of to'-oto' that have been } \\
\text { entrenched. This is the main problem that researchers want to know. } \\
\text { This research uses a qualitative research method with a phenomenal } \\
\text { research model to look deeper into the psychological meaning of an } \\
\text { individual's experience of the to'-oto' tradition. The results showed } \\
\text { that the tradition of to' -oto' was perceived as a means of returning } \\
\text { savings due to the necessities of life, a means of tightening the } \\
\text { silaturrahim rope of both the head of the family in the village or } \\
\text { outside the village, one form of "tasyakuran" (salvation) and as a form } \\
\text { of tradition that the community runs. }\end{array}$ \\
\hline $\begin{array}{l}\text { DOI: https://doi.org/ } \\
\text { @ } 2017 \text { The Authors. P }\end{array}$ & 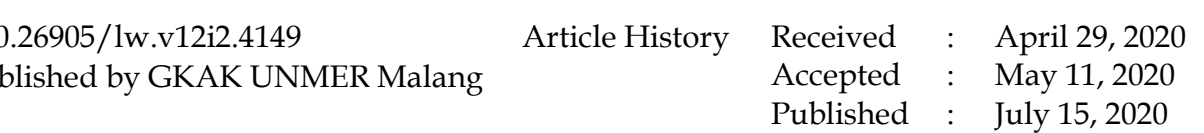 \\
\hline
\end{tabular}

\section{INTRODUCTION}

To'-oto' is an event held by Madurese Ethnic with the intention of paying or returning bhubuwan (money given at a wedding celebration) previously given by the organizer of to'-oto' to all invited guests. The existence of the tradition of $t o^{\prime}-o t o^{\prime}$ originated with the tradition of bhubuwan (giving money) in the event of a wedding celebration. At a wedding celebration, there are different gifts between men and women. The men from the family head when attending the wedding celebration will give money (bhubuwan) while women from among the mothers besides giving money (bhubuwan) also give items such as rice, sugar, or others which are called beng-nyombeng (donations). These gifts are considered by the community as savings or deposits which can later be withdrawn and considered as debt because they must be returned later so that even without going through written rules, they will automatically record them in a book that the community names bhubuwan's book, a bengsah book or jhelen's book. The book serves as a return guideline as well as a guideline for distributing invitation cards if later they will return the gift.

Abidin \& Rahman (2013) in his research also said that in bhubuwan (money given in Walimah/Marriage) held by the community of Bangkalan district Madura has a hidden 
motive in the form of investment so that the gift is as if the debt is in debt vague (khafi) who in time must be returned in time. In addition, there is an economic motivation in the provision of bhubuwan there is also a social motivation to be achieved by bhubuwan activists as value-added in the form of helping to help those who make a celebration. Substantially, bhubuwan is a combination of savings and investment. Islam encourages its adherents to save (al-iddikhar) because by saving we have prepared future needs for example to build a house, the need to build a business, or other needs. Investment capital obtained from savings funds will further reduce the burden of costs on capital because the funds are used purely private property of managers and not from third parties through debt with interest (Djalaluddin, 2014: 23). The call to save is not only for those who have a high income but also for those who have a low income are also encouraged to save for their future needs.

Giving in the wedding celebration event will usually be withdrawn when the giver held a wedding celebration event for his child but if at any time they are in a condition of needing money and want to withdraw their savings then they will hold a to'-oto' without having to wait to hold a wedding celebration event. Returns through to'-oto' are only gifts in the form of money (bhubuwan), returns are usually done by the heads of families. The process of organizing the head of the family who held a to'-oto' will invite the names of the family heads recorded in his bhubuwan's book to withdraw the bhubuwan money that the executor previously gave. To'-oto' has a rule that is formally unwritten but known to its activists, namely returning bhubuwan (money given during a wedding celebration) must return the debt of the bhubuwan twice the nominal amount of the bhubuwan previously provided by them $t o^{\prime}$-oto' executor, so if the executor of' to'-oto' previously gave bhubuwan worth Rp.100,000 thousand, then at the time of repayment he had to surrender Rp.200,000 in cash but not in terms of interest but in terms of savings (savings). Returning bhubuwan with savings (savings/deposits) which is equivalent to giving bhubuwan money implementing the to'-oto' is not something that must be among the family heads of Kamoning village, Sampang district Madura, for those who are unable to be able to return it according to their financial condition which is most important for the money give it back.

$T o^{\prime}$-oto' is also interpreted as a socio-economic act, where in addition to the motive for the return on investment there is also a motive for tightening the kinship so that the event is carried over to the overseas land. To'-oto' is understood as the cultural heritage of the ancestors who are able to bridge the inheritance of traditions from the next generation of generations but also as a means to bond with fellow ethnic groups. But more broadly, to'oto' is understood as a vehicle, a forum of silaturrahmi in increasing social solidarity between ethnic groups and being able to integrate Madurese people who are scattered throughout Surabaya (Mujib \& Ariwidodo, 2015).

The family head of Kamoning village, Sampang district Madura is one example of Madurese ethnic groups who until now still often hold to'-oto' in returning bhubuwan's money. To'-oto' has become a regular event held by the head of the family in this village every year in turn. Of course, every family head who still does it has a different interpretation in perceiving the tradition of $t o^{\prime}$-oto'. According to Shaleh \& Wahab (2004: 89), perception is the ability to discriminate, classify, focus attention on an excitatory object. While John R. Wenburg and William W. Wilmot in a book written by Mulyana (2007: 180) define perception as the way organisms give meaning. Perception involves the process of interpretation; each individual has a different interpretation depending on the experience of an object or event to be perceived. 
The essence of the to'-oto' event carried out by the family head of the Kamoning village, Sampang district Madura has its own uniqueness from the essence of the to'-oto' that is carried out by the Madurese urban community in Surabaya. If the surrender of money (bhubuwan) for the Surabaya urban community is handed over through its group leader then it will be recorded in detail by the Clerk (Mujib \& Ariwidodo, 2015) in contrast to the handing over of money (bhubuwan) by the family head of the Kamoning village, Sampang district Madura they hand over money directly (bhubuwan) to the host or party received by a host who believes because there is no group or clerk in the implementation of $t o^{\prime}$-oto' in the Kamoning village of Sampang Madura district. Each family head who carries out to'oto' certainly has different perceptions of $t o^{\prime}-$ oto $^{\prime \prime}$, which is the main objective of this research.

\section{LITERATURE REVIEW}

\section{Local Wisdom To'-oto' and Its Appearance}

The tradition of $t o^{\prime}-$ oto $^{\prime \prime}$ stems from the culture that is run by the Kamoning village community of Sampang Madura district in the form of giving money in a wedding celebration event, which they call bhubuwan. Bhubuwan which is handed over by the community is not considered as a free gift like almsgiving but rather a gift with the purpose of saving which must be returned by the recipient at the time the bhubuwan giver also holds a wedding celebration so that the gift connotes as debt. There is a need to return the gift so that even without the written rules of saving done at the wedding celebration event it is recorded in detail into a book named bhubuwan's book, bengsah book, or jhelen's book. Both the giver and the recipient have this book so that later when the return does not cause misunderstanding. This book is the basis for returning bhubuwan (money) given and also as a guide in distributing invitation cards.

In the submission of bhubuwan (money), the nominal amount surrendered by men is greater than the nominal of women this is due to the duties held by men in a family that is as a leader who has responsibility for the welfare he leads, namely his wife and his sons. In the culture of bhubuwan (giving money in the event of a wedding celebration) there is motivation to keep watch in the future (precautionary motivation) of all possibilities that will occur, especially for the head of the family who has an unstable income so that if the bhubuwan giver is in a condition of need money and intend to withdraw the bhubuwan then they can at any time withdraw the bhubuwan (money given for the wedding celebration) that was previously given by holding a to'-oto' without waiting for the wedding celebration. For some residents, holding a to'-oto' is a quick alternative to the head of the family in collecting both the bhubuwan (money) executor and the money (money that is exaggerated when returning the bhubuwan as savings).

According to the statement of Mr. Sinal as one of the research informants said that the implementation of $t o^{\prime}$-oto' was classified into two types, namely to'-oto' togghen (stamped) and $t o^{\prime}$-oto' ordinary without a stamp. To'-oto' togghen (stamped) is a $t o^{\prime}$-oto' that has a group, the identity of which is represented by a stamp. The to'-oto' has a member and submission of nominal bhubuwan along with nominal ompangan (the amount of money that is exaggerated when returning bhubuwan as savings) is relatively large, starting from around Rp. 500,000 and above so that the nominal of the bhubuwan can also be so fantastic. To'-oto' togghen has a group leader as the person in charge of the activity from the implementation to billing the members of the $t^{\prime}$ - $^{\prime}$ to $^{\prime}$ who are not present at the event. As the name implies "togghen" which means stamp, this to'-oto' has a stamp that shows its identity where when implementing $t o^{\prime}$-oto' the stamp will be affixed to the envelope or 
invitation that is distributed as well as to the flag of the guide. The economic value of the stamp means that the implementer must spend Rp.50,000 for the stamp fee, which costs will be added to the group treasury. To '-oto' is usually held by family heads who are or have a stable financial situation. To'-oto' togghen members hold to'-oto' according to the order, submission of the bhubuwan is submitted through the group leader and will be noted by the group clerk.

To'-oto' has a rule that is formally unwritten but is known by all its circumcision. $T o^{\prime}-$ oto' togghen is to'-oto' which requires its members to follow the to'-oto' rules. The rule is that returning bhubuwan (money given at the time of the wedding celebration) must return the bhubuwan's debt twice the nominal of the bhubuwan that was previously given by the $t o^{\prime}$-oto' executor, so if the to'-oto' executor previously gave bhubuwan worth Rp.100,000,000 then at the time of return through $t o^{\prime}$-oto $o^{\prime}$ had to surrender Rp.200,000. The provision of fees in accordance with the nominal of the executor is called len-balen (back and forth). The remittance given by the returner is not in the sense of interest but in the sense of savings that are deliberately kept by the returner.

Whereas the usual to'-oto' without a stamp as practiced by the family head of Kamoning village in Sampang Madura district does not have a group so there is not much cost to be incurred. In the procurement of this to'-oto' event, they themselves are in charge of the event from handing over bhubuwan to actions for invited guests who do not attend the event. The submission of the bhubuwan is handed over directly to the host and the recording will also be recorded by the organizer when the to'-oto' event ends. In addition, the deposit (savings given by the returner) to be given by the returner does not have to be in accordance with the rules of return in $t o^{\prime}$-oto' meaning the gift is adjusted to the financial condition of the giver, it does not have to be equal to what was given by the implementer of $t^{\prime}$-oto'. If there are invited guests who are not present it is the responsibility of the executor to collect it.

Because it arises and develops continuously in the community in the form of traditions that are often done and eventually become a local habit so that to'-oto' can be called local wisdom that is owned by the Sampang community. Local wisdom is the ways and practices developed by a group of people who come from their deep understanding of the local environment formed from the place of residence for generations (Meinarno et al., 2011: 98). In the discipline of Anthropology, to'-oto' is known as local wisdom.

\section{Basic Concepts of Perception}

The term perception is usually used to express the experience of something or something experienced. According to Widayatun (1999: 10), perception or response is a mental process that occurs in humans who will show how we see, hear, feel, give and feel (sense work) around us. Another definition says that perception is the ability to discriminate, classify, focus attention on an excitatory object (Shaleh \& Wahab 2004: 89). Perception involves the process of interpretation, each individual has a different interpretation depending on the experience of an object or event to be perceived, activity.

Wood (2012: 26) said that perception consists of three processes, namely selecting, organizing, and interpreting. We are more likely to perceive what we expect to be perceived. This explains the phenomenon of suggestion (self-fulfilling prophecy) where a person acts according to how he believes his own perception (Wood, 2012: 27). The first thing to note from perception is that perception is an active process whereas phenomena have no intrinsic meaning that we accept passively. In other words, we work actively to 
understand ourselves, others, situations, and phenomena. To do that we only focus on certain things and then we will selectively organize and interpret what we have noticed. Regarding the meaning or meaning of something for us, it depends on which aspects we choose and how we organize and interpret what we pay attention to. If our perceptions are inaccurate then we cannot communicate effectively because perception is the core of communication. Their perception will make us ignore other messages. Perception can also form cultural groups and identity groups, this indicates that they increasingly communicate because the degree of equality of perception between individuals is higher (Mulyana, 2007: 180).

Human perception is divided into two, namely the perception of objects (physical environment) and the perception of humans Mulyana (2007: 184). The perception of objects is perception through physical symbols, responding to external properties. Perception of objects is easier because the object is static and does not react. Then the perception of humans is the perception of people through verbal and non-verbal symbols. Perceptions of humans respond to inner and outer characteristics (feelings, motives, hopes, and so on). In this research, the perception that will be discussed regarding the perception of objects through our sensory devices to interpret the object of concern is the to'-oto' event.

\section{METHODOLOGY}

This study uses qualitative research methods with a phenomenological research model. The phenomenal research model seeks to look deeper into the psychological meaning of an individual's experience of a phenomenon in this case the to'-oto' tradition. The researcher chose Kamoning village, Sampang district Madura as the location of the study because it was at this location that the researcher caught the phenomenon of $t^{\prime}$-oto'. (Figure 1)

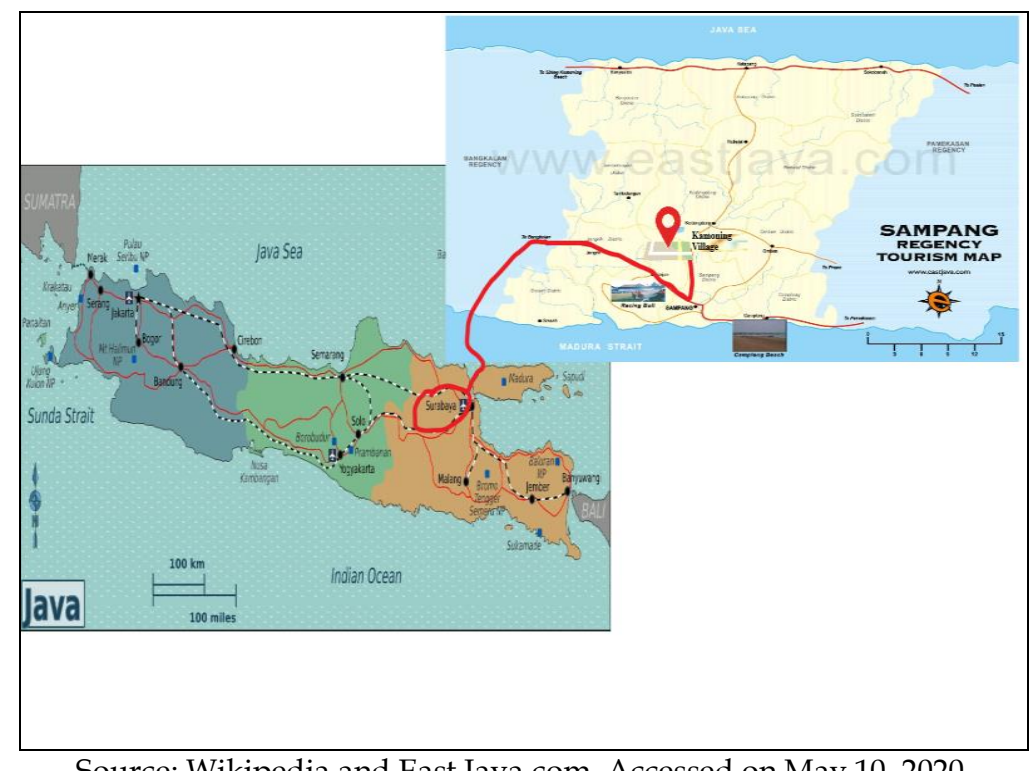

Source: Wikipedia and East Java.com, Accessed on May 10, 2020.

Figure 1. Map of Research Location

To obtain information about the purpose of this study, researchers made the heads of families who held a to'-oto' in the 2019 period as research informants. While in research data digging is done by the method of observation, interviews, and documentation. Type of research interviews using structured interviews (structure interviews). So that the informant is not rigid in conveying all of his information, conducting interviews by 
researchers is packaged as relaxed as possible like the ordinary conversation in daily life (Moleong, 2007: 187). Data analysis activities use the Milles and Huberman model which consists of three activity streams namely data reduction, data presentation, and conclusions.

\section{FINDING AND DISCUSSION}

\section{To'-oto' As a Means of Refunding Deposits Due to Life Needs}

The community considers $t o^{\prime}$-oto' as an activity held by the family head of the Kamoning village with the aim of returning bhubuwan (giving money during the wedding celebration). The family head of Kamoning village, Sampang district Madura did saving assets in the bhubuwan gift (giving money at the time of the wedding celebration), wherein the gift there was motivation to keep watch in the future (precautionary motivation) of all possibilities that would occur. The gift given is considered as a deposit (savings) that they save little by little for future life. Like savings or savings as usual, the gift of bhubuwan (money) can also be withdrawn by the giver. The necessities of life are not able to be fulfilled by the income that has been obtained so that the family heads of Kamoning village, Sampang Madura Regency held a to'-oto' to return the bhubuwan (giving money during the wedding celebration) which they had saved little by little before. The main essence of the tradition of bhubuwan and to'-oto' which is carried out by the head of the Kamoning village family of Sampang Madura district, bhubuwan can be said to be a traditional form of savings owned by the community, it has a precautionary motive or precautionary value. This is the main motivation of bhubuwan giving, which is saving money little by little and they can withdraw it at any time when in need or facing financial difficulties.

The head of the family as a leader in a family who has full responsibility for the welfare and happiness that he leads, namely his wife and children through bhubuwan provided they are on guard against all possibilities that will occur in the future, especially for the head of the family whose income is not stable so that when the head of the family who is in need of money on a fairly large scale than at any time can withdraw bhubuwan (money given in the celebration of the wedding) which he previously gave without waiting for the wedding celebration event but by holding a $t^{\prime}$-oto'. The money they save in the form of gifts at wedding celebrations or called bhubuwan can help them to face their difficult times. The similar perception of $t o^{\prime}$-oto as a means of returning savings due to the necessities of life that are found in the majority of family heads who have implemented it shows that $t 0^{\prime}$-oto' has become their culture. According to Mulyana, (2007: 180) Perception can also form cultural groups and identity groups, this indicates that they are increasingly communicating because the degree of equality of perception between individuals is higher. Both the head of the family who will return or the head of the family who will receive a return of savings (bhubuwan's money) both have records of each bhubuwan's money that has been given so that the return runs smoothly and there is no misunderstanding with one another.

\section{To'-Oto' As a Means of Tightening Sillaturrahim Ropes}

Maintaining or tightening the silaturrahim rope one of which can be realized through activity, in this case the implementation of to'-oto'. Al Ghozali (2016) in his research said that one form of axiology of silaturrahim is maintaining and increasing the affection of fellow relatives, fellow Muslims and fellow people who are applied with an attitude of knowing each other, respecting each other, exchanging greetings, visiting each other, cooperating in organizing walimah and others. Implementation of $t o^{\prime}$-oto' is a form of 
silaturrahim axiology. By holding an invited guest, he will visit the implementing house because of the bhubuwan's debt (giving money) that he has to submit. So that initially or rarely it is difficult to meet each other through the to'-oto' event they can meet and even gather in one place. Families whose gathering time is limited compared to mothers because of their work in earning a living, the existence of the $t o^{\prime}$-oto' is their meeting place, their gathering event even though the main objective is to return bhubuwan's money so that in a state of exhaustion even the Kamoning village family heads will try to make time to attend the invitation to implement the $t^{\prime}$-oto'. Awareness that the heads of families in the morning until the afternoon work so that the implementation of $t o^{\prime}$-oto' ends until the evening.

To'-oto' as a place of friendship for the family heads of Kamoning village, Sampang Madura district from those who were not familiar to became more familiar who initially did not know became familiar and who were initially difficult to meet could meet so that their fraternity expanded. In doing so, they not only hand over bhubuwan's debt, but they can share their experiences, life problems or others because the handover of bhubuwan (money) that was carried out at the to'-oto' event was handed over directly to the $t o^{\prime}$-oto' organizer, and recording activities would be carried out after the event ended so that when attending the event they talked a lot about many things instead of being handed over through their group leaders as did the Madurese urban community in Surabaya (Mujib \& Ariwidodo, 2015) so that the to'-oto' could really tighten the silaturrahim rope between the chiefs of the Kamoning village family in particular.

By maintaining silaturrahim means we maintain harmony and peace between each other so that our lives run in peace and blessings. By maintaining the silaturrahim, relations with the wider community are getting better and with a better relationship between communities, fortune opportunities will also be more widely opened because in reality, today trust is the main key in running a business.

\section{To'-Oto' As One Form of "Tasyakuran" (Salvation)}

To'-oto' is perceived as a form of "tasyakuran" (salvation) because in the implementation of' to-oto ' there is an expression of gratitude for all the blessings that Allah has bestowed. Organizers who perceive to'-oto' as a thanksgiving event and have enough money will invite the clerics or other religious leaders to perform khotmil Qur'an activities (khataman Al-Qur'an) after completion will send prayers to parents and relatives who have died and do not forget to say a prayer for the safety of the entire family of the executor of to'-oto'. One of the characteristics possessed by Madurese people is their religious community. Siahan (2003: 12) in Rochana (2012: 48) said that Madurese respect more religious institutions and scholars compared to state institutions and their apparatus. Continuing from what Siahan said in Rochana, Hefni (2007: 16) in his research that the Kyai gained a place in the hearts of the Madurese community, especially for rural communities who put the kyai as worldly and ukhrawi leaders. Madura's ecological conditions based on dry fields also support the construction of these communities. In building a house both in a village or village settlement structure is different from the structure of community settlements in Java, namely in one yard consisting of several families who still have kinship relations, such settlement patterns are called kampong Meji. It is this Meji village that forms small villages and, in each village, has a religious center in the form of a mosque or a langgar where the leader is a kyai. Supported by this ecological factor, it gave birth to social organizations that relied on religion and religious scholars. 


\section{To'-Oto' As a Form of Tradition That Is Carried Out}

To'-oto' is perceived as a form of tradition because this event has been held for a long time and has been carried on for generations by Madurese from various generations. $T o^{\prime}-$ oto' has become a way of life that they have. To'-oto' is categorized a culture in the form of a social system and in the form of a system of ideas. It is said as a culture in the form of a social system because to $^{\prime}$-oto' is a form of human activities that interact and relate and interact with one another. While it is said to be a culture in the form of an idea system because to'-oto' contains cultural values in each of its executors. Koentjaraningrat, (1996: 75) said that the form of ideas from culture is in the heads of each individual citizen of the culture concerned so that it will be taken wherever he goes. In accordance with what was described by the Koentjaraningrat, the implementation of the to'-oto' was carried to overseas. In his research, Mujib \& Ariwidodo (2015) explained that the Madurese urban community in Surabaya understands the implementation of $t o^{\prime}$-oto' as an ancestral cultural heritage that is able to bridge the inheritance of traditions from the next generation of generations and as a means to bond with fellow ethnic groups. But more broadly as a vehicle, silaturrahmi forum in increasing social solidarity between ethnic groups, and able to integrate Madurese people who are scattered throughout Surabaya.

To'-oto' can be a unique and distinctive identity of the Madurese ethnicity so that it can also be said to be a pearl of local wisdom. Even though the current of modernization is getting stronger, the tradition of $t o^{\prime}$-oto' up to now is still preserved as practiced by the family head of Kamoning village, Sampang Madura district, every year they carry on this tradition alternately only the number of implementers is uncertain because there is no schedule for the implementation.

\section{CONCLUSION}

The tradition of to'-oto' among the Family head of the Madurese Ethnic in the Kamoning village of Sampang Regency gave birth to various perceptions from the implementers, among others, as a means of returning savings due to the necessities of life. The family head of Kamoning village, Sampang district Madura did saving assets in the bhubuwan gift (giving money at the time of the wedding celebration), wherein the gift there was motivation to keep watch in the future (precautionary motivation) of all possibilities that would occur so that when the giver was being facing financial difficulties they can withdraw their deposits at any time without having to wait for a wedding celebration. As a means of tightening the silaturrahim rope, the implementation of this to'-oto' became the venue for their meeting, the gathering of the heads of ethnic Madurese families. or it's hard to meet each other through $t o^{\prime}$-oto' events they can meet and even gather in one place. To'oto' As a form of celebration program (salvation). "Tasyakuran" (salvation) is shown by inviting the clerics or other religious leaders to carry out the activities of khotmil Qur'an (khataman Al-Qur'an) after completion will send prayers to parents and relatives who have died and did not forget to say a prayer for the safety of the entire family of implementers of the $t o^{\prime}$-oto' As a form of tradition that is carried out, to'-oto' contains cultural values in each of its executors and will be carried wherever the practitioners go.

\section{References}

Abidin, Zainal dan Holilur Rahman. (2013). “Tradisi Bhubuwan Sebagai Model Investasi Di Madura", KARSA, 21(1), 104-115. 
Al Ghozali, M. Dzikrul Hakim. (2016). “Silaturrahim Perspektif Filsafat Islam (Ontologi, Epistimologi dan Aksiologi)", Dinamika, I(I), 51-66.

Djalaluddin, Ahmad. (2014). Manajemen Qur'ani: Menerjemahkan Idarah Ilahiyah dalam Kehidupan (Seri Integritas), UIN-Maliki Press, Malang.

Hefni, Moh. (2007). “Bhuppa'-Bhabhu'-Ghuru-Rato (Studi Kontruktivisme-Strukturalis Tentang Hierarkhi Kepatuhan dalam Budaya Masyarakat Madura)", KARSA, XI(I), 13-20.

Koentjaraningrat. (1996). Pengantar Antropologi I, PT Rineka Cipta, Jakarta.

Meinarno, Eko A., Bambang Widianto, dan Rizka Halida. (2011). Manusia dalam Kebudayaan dan Masyarakat: Pandangan Antropologi dan Sosiologi. Jakarta: Salemba Humanika.

Miles, Matthew B., dan A. Michael Huberman. (1992). Analisis Data Kualitatif: Buku Sumber Tentang Metode-Metode Baru, Universitas Indonesia (UI-Press), Jakarta.

Moleong, Lexy. (2007). Metodologi Penelitian Kualitatif, PT REMAJA ROSDAKARYA, Bandung.

Mujib, Fatekhul. dan Eko Ariwidodo. (2015). “Tradisi Oto'-Oto'; Integrasi Sosial Masyarakat Urban Madura Di Surabaya" , KARSA, 12(1), 2-17.

Mulyana, Deddy. (2007). Ilmu Komunikasi: Suatu Pengantar, PT. REMAJA ROSDAKARYA, Bandung.

Rochana, Totok. (2012). “Orang Madura:Suatu Tinjauan Antropologis”. Humanus. XI(1), 4651.

Shaleh, Abdul Rahman. dan Muhbib Abdul Wahab. (2004). Psikologi Suatu Pengantar (Dalam Perspektif Islam), Kencana, Jakarta.

Widayatun, Tri Rusmi. (1999). Ilmu Perilaku, CV. Sagung Seto, Jakarta.

Wood, Julia T. (2012). Komunikasi: Teori dan Praktik (Komunikasi dalam Kehidupan Kita), Salemba Empat, Jakarta.

https://mg.m.wikipedia.org/wiki/Sary:Java_region_map.png accessed on May 10, 2020

https://www.indonesia-tourism.com/east-java/tourism/sampang/map.html accessed on May 10, 2020 